African Journal of Biotechnology Vol. 11(78), pp. 14297-14304, 27 September, 2012

Available online at http://www.academicjournals.org/AJB

DOI:10.5897/AJB12.1053

ISSN 1684-5315 @2012 Academic Journals

\title{
The effects of the pine sac beetle (Thaumetopoea pityocampa Schiff.) on total phenolic compounds and photosynthetic pigment contents in pine species (Pinus nigra L. and Pinus brutia Ten.)
}

\author{
Aysel SIVACI ${ }^{1 \star}$, Emire ELMAS ${ }^{2}$, Nevin BOZKURT ${ }^{3}$ and Sevcan DUMAN ${ }^{4}$ \\ ${ }^{1}$ Department of Biology, Art and Science Faculty, Adıyaman University, Adıyaman, Turkey. \\ ${ }^{2}$ Department of Biology, Art and Science Faculty, Sinop University, Sinop, Turkey. \\ ${ }^{3}$ Graduate School of Sciences, Sinop University, Sinop, Turkey. \\ ${ }^{4}$ Graduate School of Sciences, Adıyaman University, Adıyaman, Turkey.
}

Accepted 1 August, 2012

\begin{abstract}
The purpose of this study was to investigate the effects of the pine sac beetle (Thaumetopoea pityocampa Schiff.) on the pigments (chlorophyll $a$, chlorophyll $b$ and carotenoids) and total phenolic compounds in the Pinus nigra L. and Pinus brutia Ten. spread throughout the forest areas in the Boyabat District of the Sinop Province. It was found that chlorophyll $a$, chlorophyll $b$ and carotenoids contents were lower on the leaves of the $P$. nigra and $P$. brutia which had pine sac beetles in comparison to those not having pine sac beetles. It was also observed that the contents of chlorophyll $a$ and chlorophyll $b$ were decreased on the stems of both species but there was no significant change in the contents of carotenoid. The phenolic compound levels increased in the leaves and the stems of $\boldsymbol{P}$. nigra and $P$. brutia which had pine sac beetles compared to those that did not have pine sac beetles.
\end{abstract}

Key words: Phenolic compounds, photosynthetic pigments, Pinus nigra, Pinus brutia, Thaumetopoea pityocampa.

\section{INTRODUCTION}

Generating mutual relations, forests are ecosystems that are made up of trees and live creatures such as other plants, animals and microorganisms along with physical environmental factors. Insect damages are one of the most important factors that threaten forests (Avci, 2000). The pine sac beetle (Thaumetopoea pityocampa Schiff.) is one of the common insect species in Anatolia and by means of eating the needles of the pine species which make up a large portion of Anatolia forests, it is an

*Corresponding author. E-mail: asivaci@adiyaman.edu.tr. Tel: (416)2231775. Fax: +90 (416)2231774. important pest due to a cause for increment loss of Anatolia trees (Durkaya et al., 2009; Kanat et al., 2005). The pine sac beetle has spread throughout the southern Europe and the north of Africa (Battisti et al., 2000; Devkota and Schmidt, 1990; Breuer et al., 1989). It is common in warm regions, which are under the influence of Mediterranean climate in Anatolia (Çanakcioğlu, 1983; Kanat and Türk, 2002).

Damaging the large areas of the forests, the pine sac beetles cause up to $60 \%$ increment loss to calabrian pines (Pinus brutia), larch (Pinus nigra) and to other pine species (Anonymous, 1995). The pine sac beetles damage the leaves of the pines by eating them during the larva periods. In the event that their numbers are less, 
they denudate the pines like an epidemic while they are damaging the leaves around their sacs. Depending on the amount of the feedings during advanced larval stages, their damage increases and the damage peaks to the highest level during the last larval phase (Devkota and Schmidt, 1990). Disruptions occur on the photosynthetic physiology of the pines whose leaves have been eaten and their growth slows down. Mainly mechanical, chemical and biological methods are used to perform the fight against the damages caused by the pine sac beetles. The studies conducted mostly have been focused on the struggles of the pine sac beetle but it is seen that the number of studies associated with how the physiologies of the pine species change towards such herbivore stress is insufficient. This study investigated the effects of the pine sac beetle (Thaumetopoea pityocampa) on the pigments (chlorophyll a, chlorophyll b and carotenoids) and total phenolic compounds in the stem and the leaves of the $P$. nigra $\mathrm{L}$. and $P$. brutia Ten. within a forest area in the Boyabat district of the Sinop province.

\section{MATERIALS AND METHODS}

$P$. nigra and $P$. brutia species common at the forest areas of the Boyabat district in the Sinop province between 2010 and 2011 were used in this study; samples from their stems and leaves which had pine sac beetles and samples from those that did not have were obtained. Also, samples were taken from the healthy branches of the infected individuals. Total pigments and phenolic compounds were analyzed on the samples obtained.

Determining the total contents of chlorophyll a, chlorophyll b and the carotenoids

The pine sac beetle and non-pine sac beetle samples obtained from the stems and leaves of $P$. nigra and $P$. brutia were extracted in accordance with De Kok and Graham (1989). The samples were read at 662 and $645 \mathrm{~nm}$ for the chlorophylls and $470 \mathrm{~nm}$ for carotenoids. Their amounts were calculated according to Lichtenthaler and Wellburn (1983).

\section{Determining the total phenolic compounds}

Pine sac beetle and non-pine sac beetle samples from the stems and leaves of the $P$. nigra and $P$. brutia were determined in association with the Folin reactive and standard gallic acid equivalence and in accordance with the literature methods given below (Slinkard and Singleton, 1977; Chandler and Dodds, 1983). The phenolic compound amounts were read at the $760 \mathrm{~nm}$ absorbance and calculated based on the standard gallic acid equivalence.

\section{Statistical analysis}

Statistical analysis was performed using SPSS 15.0 software.
Duncan's test (1955) was used for significance control $(P<0.05)$ following variance analysis.

\section{RESULTS}

It was found that the amounts of chlorophyll a, chlorophyll $\mathrm{b}$ and carotenoids in the leaves of the $P$. brutia individuals which had pine sac beetles decreased in comparison to the healthy ones that did not have the pine sac beetles $(P<0.05)$. It was found that chlorophyll $a$, chlorophyll $b$ and carotenoids amounts in leaves taken from the sections, which were away from the sac of the individual having the pine sac beetle decreased compared to the healthy individuals. However, this decrease was much lower than that of the areas where the pine sac beetles were situated $(P>0.05$; Figure 1$)$. The chlorophyll $a$ and chlorophyll $b$ amounts on the stems of the $P$. brutia containing the pine sac beetles decreased compared to the healthy non-sac beetle ones $(P<0.05)$; but there was no significant change in their carotenoid contents $(P>0.05$; Figure 1$)$.

It was found that chlorophyll $\mathrm{a}, \mathrm{b}$ and carotenoid amounts on the leaves and stems of the Pinus nigra, which contained the pine sac beetle were lower in comparison to the healthy ones that did not contain the pine sac beetle $(P<0.05$; Figure 2$)$. On the leaf and stem taken from individual having the pine sac beetle, pigment (chlorophyll a, b and carotenoids) amounts obtained from the sections where the sacs of the pine beetles were away decreased compared to the healthy ones but this decrease was much lower than the sections where the beetle was situated; similar to the $P$. brutia (Figure 2).

It was observed that the total chlorophyll amounts on the leaves and stems of both the species ( $P$. nigra and $P$. brutia), which contain the pine sac beetle decreased compared to the healthy ones without the pine sac beetles $(P<0.05$; Table 1$)$.

When examining the phenolic compound changes on the $P$. brutia and $P$. nigra, it was found that the changes increased on both the species that contained the pine sac beetle in comparison to those that did not (Figure 3). While the phenolic compound amounts on the leaves of the $P$. brutia that contained the pine $\operatorname{sac}(P>0.05)$. On the stem samples of the $P$. brutia, the phenolic compound amount on the individuals whichcontained the pine sac beetles increased compared to those that did not just like the leaves $(\mathrm{P}<0.05$; Figure 3$)$.

It was also found that on the leaves and stems of the beetle was $3.16 \mu \mathrm{g} \mathrm{mg}^{-1}$, this amount was $2.6 \mu \mathrm{g} \mathrm{mg}^{-1}$ on the healthy ones that did not $(P>0.05)$. However, it was found that the phenolic compound amounts on the leaves obtained from the healthy sections of the tree, which contained the pine sac beetle was lower than the ones obtained from sections where the sac was located $P$. 


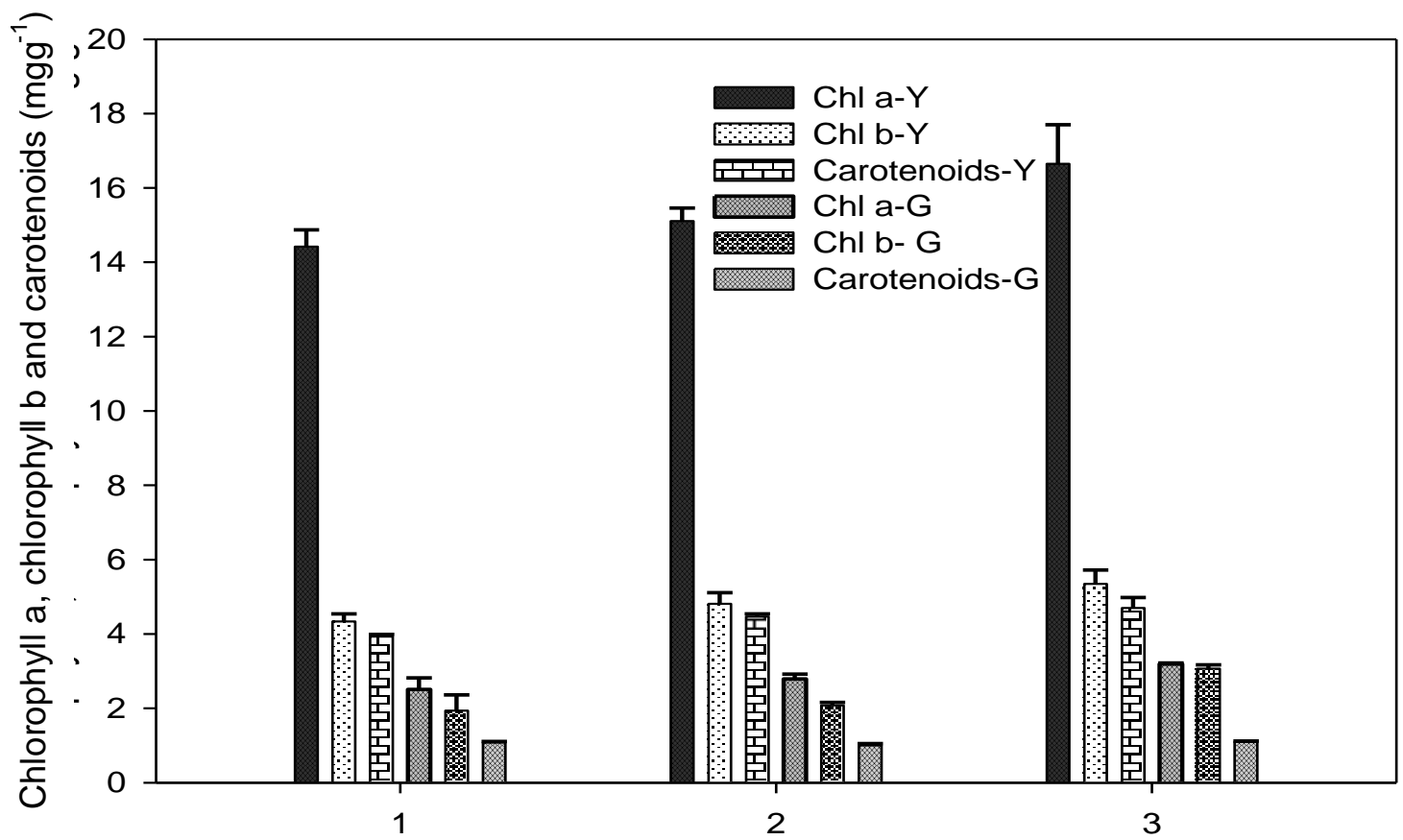

Figure 1. Changes in total chlorophyll $a$, chlorophyll $b$ and carotenoids on the pine sac beetle and non-pine sac beetle leaves and stems of the P. brutia ( $\mathrm{mg} \mathrm{g}^{-1}$, fresh weight). 1, those containing the pine sac beetle; 2 , those containing the pine sac beetle but being healthy; 3 , those not containing the pine sac beetle; Chl a, chlorophyll a; Chl b, chlorophyll b; Y, leaf; G, Stem.

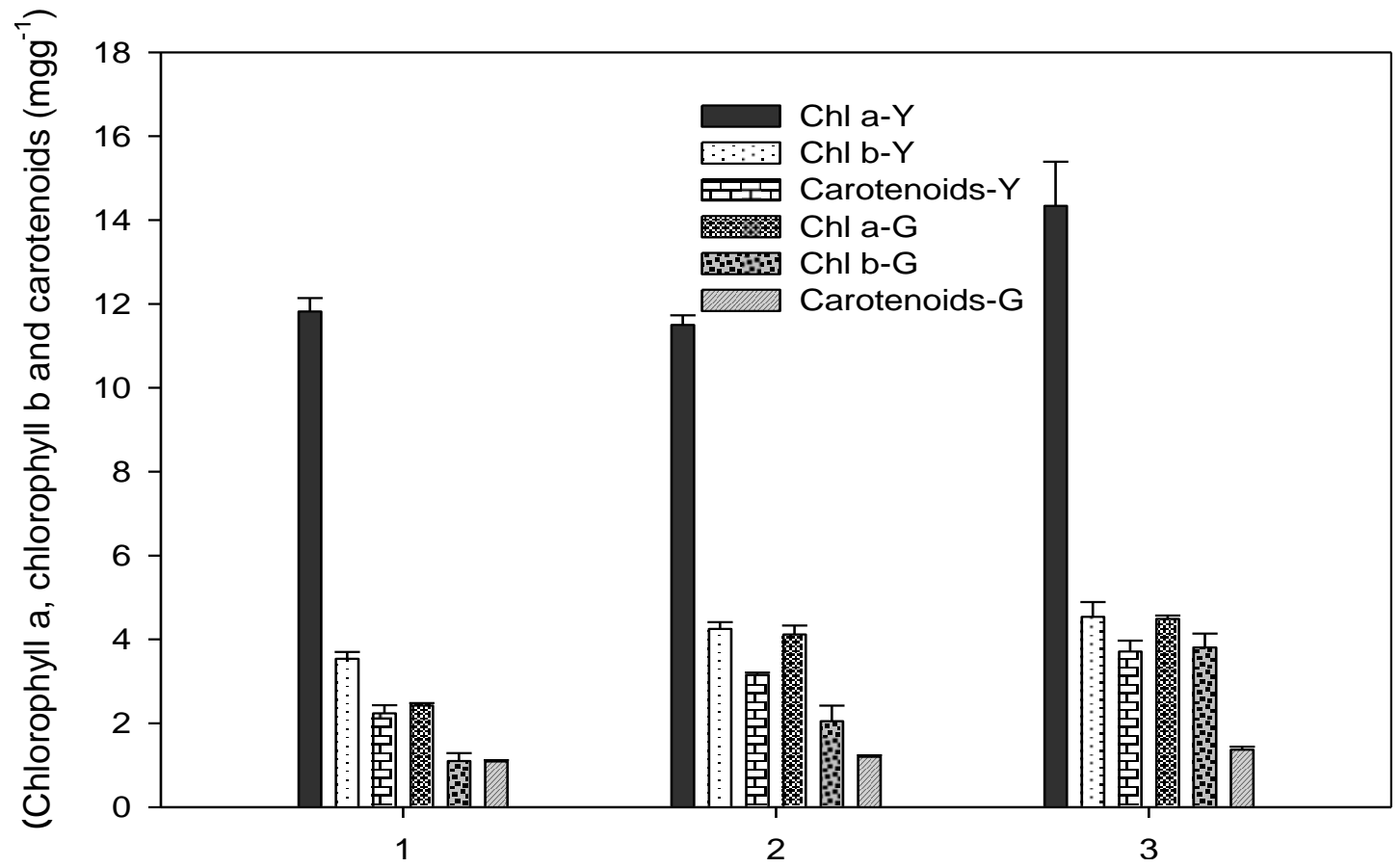

Figure 2. Changes in total chlorophyll $a$, chlorophyll $b$ and carotenoids on the pine sac beetle and non-pine sac beetle leaves and stems of the $P$. nigra ( $\mathrm{mg} \mathrm{g}^{-1}$, fresh weight). 1 , those containing the pine sac beetle; 2 , those containing the pine sac beetle but being healthy; 3 , those not containing the pine sac beetle; Chl a, chlorophyll a; Chl b, chlorophyll b; Y, leaf; G, stem. 


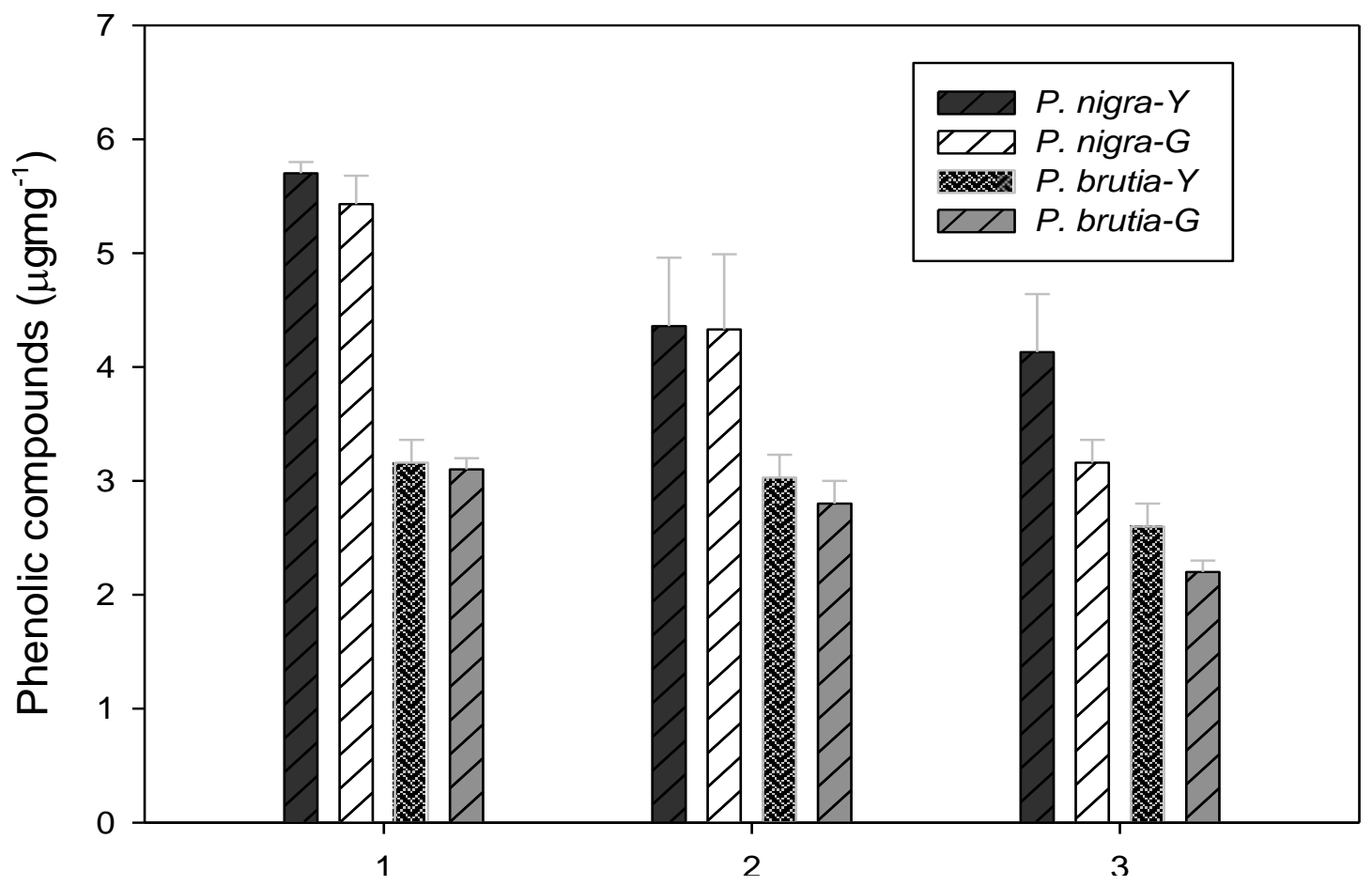

Figure 3. Changes in total phenolic compounds on the pine sac beetle and non-pine sac beetle leaves and stems of the $P$. nigra and $P$. brutia ( $\mu \mathrm{g} \mathrm{mg}^{-1}$, fresh weight). 1 , Those containing the pine sac beetle; 2 , those containing the pine sac beetle but being healthy; 3 , those not containing the pine sac beetle; Chl a, chlorophyll a; Chl b, chlorophyll b; Y, leaf; G, stem.

nigra which consisted of pine sac beetles, the phenolic compounds increased in comparison to those that did not have $(P<0.05)$ (Figure 3). However, when the phenolic compound accumulations of both the species against this type of herbivore stress were examined, the $P$. nigra's accumulation was higher than the $P$. brutia's $(P<0.05$ (Figure 3).

\section{DISCUSSION}

The biotic and abiotic stresses cause changes in the physiologies and morphologies of the plants (Levitt, 1972; Madhava Rao et al., 2006). The healthy trees were weaken with the attacks of the pine sac beetles and cause the trees to be more sensitive to the factors such as drought, pathogens and other herbivores. When viewed from this aspect, the pine sac beetle is the primary harmful insect. The secondary pests increased in numbers in some years and caused the deadly dissolution of significant amount of trees in the areas, which were weakened due to the impact of the pine sac beetle and other primary pests (Avci and Oğurlu, 2002; Babur, 2002; OGM, 1995, 1998). The studies conducted concluded that along with insect feeding, there was also chlorosis and chlorophyll loss in wheat in terms of plant damage (Heng-Moss et al., 2004; Wang et al., 2004). In the study conducted on the Eucalyptus trees by Khattab and Khattab (2005), they found that there were changes in the anatomic structure and physiologies of the gallcreating and non-gall-creating leaves. They reported that the $\mathrm{Ca}^{2+}, \mathrm{Mg}^{2+}$, pigment levels, carbohydrates, amino acids, lignin, and soluble protein contents were less on the leaves of the diseased individuals than on those which are healthy. This study concluded that the pigment amounts decreased on the leaves and stems of the $P$. brutia and $P$. nigra based on the impact of the pine sac beetles (Figures 1 and 2). The reason for this decrease may be the loss of the photosynthesis tissue functions (Harborne, 1980). The studies conducted reported that the plants develop a variety of defence damageaccumulated reactive oxygen species on the pigment (Stacey and Keen, 1996).

Plants need phenolic compounds for pigmentation, growth, production, pathogen resistance and for many which is related to the pine sac beetles eating the leaves. In addition, as presented in some studies, because the herbivore damage harms the xylem tissue on the trees, it 
Table 1. Total chlorophyll changes on the pine sac beetle and non-pine sac beetle leaves and stems of the $P$. nigra and $P$. brutia ( $\mathrm{mg} \mathrm{g}^{-1}$, fresh weight).

\begin{tabular}{ccccc}
\hline & \multicolumn{2}{c}{ Pinus brutia } & \multicolumn{2}{c}{ Pinus nigra } \\
\cline { 2 - 5 } S/N & \multirow{2}{*}{ Leaf } & Stem & Leaf & \multirow{2}{*}{ Stem } \\
\hline 1 & $18.76 \pm 0.65$ & $4.45 \pm 0.73$ & $15.36 \pm 0.48$ & $3.52 \pm 0.25$ \\
2 & $19.92 \pm 0.65$ & $4.87 \pm 0.21$ & $15.75 \pm 0.39$ & $6.17 \pm 0.58$ \\
3 & $22 \pm 1.42$ & $6.26 \pm 0.13$ & $18.88 \pm 1.35$ & $8.30 \pm 0.41$ \\
\hline
\end{tabular}

1 , Those containing the pine sac beetle; 2 , those containing the pine sac beetle but being healthy; 3 , those not containing the pine sac beetle.

can also be caused by the inability to carry the necessary mineral matter for pigment synthesis or the effect of the reactions against herbivores. In general, the plant can use metabolites and macromolecules (peptides, proteins, enzymes, lignin, and phenolic metabolites) as a defence against herbivores (Wink, 1997; Gutterman and ChauserVolfson, 2000). Hódar et al. (2004) reported that there is a relationship between the pine sac beetle and the host defence system. In the studies conducted by these researchers, they found that the mortality rate of larvae in the previously damaged trees was significantly higher than those that have not suffered damage. Khattab and Khattab (2005) reported in their study on the Eucalyptus trees that the total phenol and tannin amounts increased in the gall-creating leaves in comparison to the non-gallcreating leaves. This study found out that the phenolic compound amounts on the leaves and stems of both the species consisting of the pine sac beetle increased compared to the species that did not consist of the pine sac beetle and that it showed variability depending on the plant species (Figure 3).

In conclusion, it has been determined that the pine sac beetle damaged both these pine species thereby causing a change in their physiology. In parallel with this damage, a decrease in the pigment levels was observed along with an increase in the phenolic compounds for the purposes of defence. For future studies to be conducted, it is important to determine the physiologies of the pine species against such herbivore stress and to create strategies in order to increase resistance against these types of damages.

\section{ACKNOWLEDGEMENTS}

Authors are thankful to Gülçin Yılmaz Küçükbaş who is responsible for the biological control laboratory in Boyabat forest district offices for her help in the field studies.

\section{REFERENCES}

Anonymous (DPT) (1995). Forestry Report by DPT, Ankara. p.183.

Avci M (2000). Investigation on structure of egg-batches, parasitism and egg laying habits of Thaumetopoea pityocampa (Den. \& Schiff.) (Lep., Thaumetopoeidae) in various regions of Turkey, Turkish $\mathrm{J}$. Entomol. 24:167-178.

Avci M, Oğurlu I (2002). Pine beetle sac [Thaumetopoea pityocampa (Den.\&Schiff.)] in pine forests of lakes region [Thaumetopoea pityocampa (Den. \& Schiff.)]. The importance, biology and natural enemies, pine processionary moth problem in our country forests and Solutions Symposium Proceedings book, pp. 28-36.

Babur H (2002). The amount of damage in the pine youth of Thaumetopoea pityocampa (Schiff.), problem pine processionary moth in our country forests and Solutions Symposium Proceedings book, pp. 37-51.

Battisti A, Bernardi M, Ghiraldo C (2000). Predation by the hoopoe (Upupa epops) on pupae of Thaumetopoea pityocampa and the likely influence on other natural enemies, Biol.Control. 45(3):311-323.

Breuer M, Devkota B, Douma-Petridou E, Koutsaftikis A, Schmidt GH (1989). Studies on the exposition and temperature of nests of Thaumetopoea pityocampa (Den. \& Schiff.) (Lep.: Thaumetopoeidae) in Greece, J. Appl. Entomol. 107(4):370-375.

Chandler SF, Dodds JH (1983). The effect of phosphate, nitrogen and sucrose on the production of phenolics and solasidine in callus cultures of Solanum lacinitum. Plant Cell Rep. 2:105.

Çanakcioğlu H (1983). Forest entomology (special section), University of Istanbul, Faculty of Forestry Press, Istanbul (Publication No: 3623, Faculty Publication pp. 382-385).

De Kok LJ, Graham M (1989). Level of pigments, soluble proteins, amino acids and sulphydryl compounds in foliar tissue of Arabidopsis thaliano during dark-induced and natural senescence. Plant Physiol. Biochem. 27:203-209.

Devkota B, Schmidt GH (1990). Larval development of Thaumetopoea pityocampa (Den. \& Schiff.) (Lep., Thaumetopoeidae) from Greece as influenced by different host plants under laboratory conditions, J. Appl. Entomol. 109(4):321-330.

Duncan DB (1955). Multiple range and multiple $F$ tests biometrics. 11-114.

Durkaya A, Durkaya B, Dal I (2009). The effects of the pine processionary moth on the increment of crimean pine trees in Bartin, Turkey Afr. J. Biotechnol. 8 (10):2356-2361.

Gutterman Y, Chauser-Volfson E (2000). The distribution of the phenolic metabolites barbaloin, aloeresin and aloenin as a peripheral defense strategy in the succulent leaf parts of Aloe arborescens. Biochem. Syst. Ecol. 28:825-838.

Harborne JB (1980). Secondary Plant Products, Bell, E.A and Charlwood, B.W. (Eds), Enciclopedia of Plant Physiology, New Series, Vol. 8. Springer-Verlag, Berlin, p. 329. 
Heng-Moss TG, Sabath F, Baxendale D, Novak S, Bose X, Ni Quisenberry S, (2004). Characterization of oxidative enzyme changes in buffalograsses challenged by Blissus occiduus. J. Econ. Entomol. 97:1086-1095.

Hódar JA, Zamora R, Castro J, Baraza E (2004). Feast and famine: previous defoliation limiting survival of pine processionary caterpillar Thaumetopoea pityocampa in Scots pine Pinus slvestris, Acta Oecol. 26:203-210.

Khattab H, Khattab I (2005). Responses of Eucalypt trees to the insect feeding (Gall- Forming Psyllid). Int. J. Agri. Biol. 7(6):979-984.

Kanat M, Türk M (2002). The pine processionary moth (Thaumetopoea pityocampa (Schiff.)) method to combat a new cage, pine processionary moth problem in our country forests and Solutions Symposium Proceedings book, pp. 109-113.

Kanat M, Alma H, Sivrikaya F (2005). Effect of defoliation by (Thaumetopoea pityocampa Den. \& Schiff.) (Lepidoptera: Thaumetopoeidae) on annual diameter increment of (Pinus brutia Ten.) in Turkey. Ann. Forest Sci. 62:91-94.

Levitt J (1972). Responses of plants to environmental stress. Academic Press, London. $697 \mathrm{Pp}$.

Lichtenthaler HK, Wellburn AR (1983). Determination of total carotenoids and chlorophylls $a$ and $b$ of leaf extracts in different solvents. Biochem. Soc. Trans. 11:591-592.

Madhava Rao KV, Raghavendra RS, Janardhan Reddy K (2006). Physiology and molecular biology of stress tolerance in plants. Springer Publishing, The Netherlands.
OGM (1995). Ministry Brochures Ministry of Forestry Department of Forest Protection And Fire Fighting, K.2/114.

OGM (1998). Ministry Brochures Ministry of Forestry Department of Forest Protection and Fire Fighting, K.2/197 "Pine Processionary Moth Combat".

Slinkard K, Singleton VL (1977). Total phenol analyses: automation and comparison with manual methods. Am. J. Enol. Vitic. 28:49-55.

Stacey G, Keen NT (1996). Plant-Microbe Interactions. Aps Press, Minnesota. Vol.1. $316 \mathrm{Pp}$.

Wang T, Quisenberry SS, Ni X, Tolmay V (2004). Enzymatic chlorophyll degradation in wheat near-isogenic lines elicited by cereal aphid (Homoptera: Aphididae) feeding. J. Econ. Entmol. 97:661-667.

Wink M (1997). Compartmentation of secondary metabolites and xenobiotics in plant vacuoles. Advances Bot. Res. 25:141-169. 